\title{
DEVELOPMENT OF A SET OF CRITERIA AS AN ECO-DESIGN TOOL FOR EVALUATION OF ENVIRONMENTAL IMPACT OF MATERIAL CHOICE
}

\section{KRITĒRIJU KOPAS KĀ EKODIZAINA INSTRUMENTA IZSTRĀDE IZVĒLĒTO MATERIĀLU IETEKMES UZ VIDI NOVERTËŠANAI}

\author{
J.Simanovska, Msc. Env., Researcher \\ Riga Technical University, Institute of Energy Systems and Environment \\ Adress: Kronvalda boulv.1, LV-1010, Riga, Latvia \\ Phone.: +371 7089908, Fax: +371 7089908 \\ e-mail: jana.simanovska@rtu.lv \\ K. Valters, Dr.chem., Assistant Professor \\ Riga Technical University, Faculty of Power and Electrical Engineering \\ Institute of Energy Systems and Environment \\ Adress: Kronvalda boulv.1, LV-1010, Riga, Latvia \\ Phone.: +371 7089908, Fax: +371 7089908 \\ e-mail: karlis@,norden.lv \\ G. Bažbauers, Dr.sc.ing., Professor \\ Riga Technical University, Institute of Energy Systems and Environment \\ Adress: Kronvalda boulv.1, LV-1010, Riga, Latvia \\ Phone.: +371 7089908, Fax: +371 7089908 \\ e-mail: bazbauer@latnet.lv
}




\section{Introduction}

Eco-design is a part of the product design process aimed at reducing environmental impacts of the product during its whole lifecycle. Nowadays, the eco-design concept becomes more and more important, and it is also incorporated in the latest legislation developments [1], despite the fact that enterprises, in particular small ones, are hesitant to implement eco-design. There are many tools developed in order to facilitate the implementation of eco-design into real life, however "eco-design techniques may not have been more widely adopted by businesses because such methods are not necessarily generic and immediately applicable, but instead must include some form of process-specific customisation prior to use" [2].

Eco-design very often starts with an investigation of the environmental impacts of the current product, and the most comprehensive method for this purpose is Life Cycle Assessment (LCA). The quotation above is true of the LCA - despite the comprehensiveness and scientific soundness of this method, many practitioners avoid using it. Practitioners were asked to choose the most suitable eco-design tools and among 15 tools which support the eco-design process, the LCA placed $14^{\text {th }}[2]$. The most favourable applications were checklists, eco-ideas' maps, environmental effect analysis and guidelines [2].

In order to promote eco-design in the industry, there is a need for the further development of more practical tools, taking into account scientific findings, but also making them applicable in the product design process. The objective of this paper is to present the main considerations in order to develop a set of criteria for the material choice taking into account LCA studies and available data regarding the environmental performance of materials.

\section{The importance of the material choice: example of LCA findings regarding personal desktop computers}

The importance of the material choice can be illustrated with an example of LCA studies. One of the products analysed in several LCA studies is the desktop personal computer in Korea 2006[3], EU 1998 [4], EU 2005 [5], EU 2006 [6], and China 2009 [7]. Each of these studies have chosen a different methodology for the LCA and thus the results are not easy to compare and interpret. One important drawback of the above-mentioned studies is the fact that currently the LCA methodology regarding the impact assessment of chemicals is underdeveloped as only some of the endpoints for human toxicity are considered [6]. Therefore, not all of the above mentioned studies have included the impact category related to chemicals, e.g., EU 1998 [4] has not included human toxicity as an impact category, but have considered the potential effects separately outside the scope of the LCA.

The results indicate that the major impacts are caused by two aspects - 1) material use and recycling (extraction of materials, processing, recycling, landfilling) and 2) energy use during the use phase. There is a sense to separate reduction of energy use and optimization of the material choice during the product development process, since the real actions lie in separate engineering areas.

Material use causes environmental impact mainly due to the energy consumed during production and processing, as well as due to the resources depleted during extraction, and due to the toxic effects created during the whole lifecycle. Also, depending on the endof-life scenario and how much of the product can be recycled - the total environmental impact can be decreased. 
Aspects of material selection in the environmental product design

Table 1.

\begin{tabular}{|c|c|c|}
\hline Author & Environmental aspects of material selection & $\begin{array}{c}\text { Quantifiable } \\
\text { criteria }\end{array}$ \\
\hline $\begin{array}{l}\text { Ashby, } \\
\text { Johnson [9] }\end{array}$ & $\begin{array}{ll}\text { Eco-attributes: } & \text { Energy content }(\mathrm{MJ} / \mathrm{kg}) \\
& \text { Potential for recycling (high }- \text { low) }\end{array}$ & $\begin{array}{l}\text { Partly } \\
\text { provided }\end{array}$ \\
\hline $\begin{array}{l}\text { Eco-design } \\
\text { Pilot [10] }\end{array}$ & $\begin{array}{l}\text { - } \text { Good environmental performance } \\
\text { - Avoid (reduce) the use of toxic materials } \\
\text { - Prefer renewable raw materials } \\
\text { - Prefer recyclable materials } \\
\text { - Avoid inseparable composite materials } \\
\text { - Avoid raw materials of problematic origin }\end{array}$ & Not provided \\
\hline $\begin{array}{l}\text { Luttropp, } \\
\text { Lagerstedt } \\
{[11]}\end{array}$ & $\begin{array}{l}\text { - } \begin{array}{l}\text { Do not use toxic substances and utilize closed loops for } \\
\text { necessary but toxic substances }\end{array} \\
\text { - Use structural features and high quality materials to minimize } \\
\text { weight } \\
\text { - Promote repair and upgrading } \\
\text { - Promote long life, esp. for products with significant } \\
\text { environmental aspects outside of the usage phase } \\
\text { - Invest in better materials, surface treatments or structural } \\
\text { arrangements to protect products from dirt, corrosion and wear } \\
\text { - Prearrange upgrading, repair and recycling } \\
\text { - Promote upgrading, repair and recycling by using few, simple, } \\
\text { recycled, not blended materials and no alloys } \\
\text { - Use as few joining elements as possible, use screws, adhesives, } \\
\text { welding, snap fits, geometric locking }\end{array}$ & Not provided \\
\hline $\begin{array}{l}\text { Ozolinňs, } \\
\text { Geriňš [12] }\end{array}$ & $\begin{array}{l}\text { - Nature protection } \\
\text { - Environmental pollution during extraction and production of } \\
\text { - Taw materials, production and use of product } \\
\text { - Soxicity by use and accidents } \\
\text { - } \text { Recyclability }\end{array}$ & Not provided \\
\hline Nissen [13] & $\begin{array}{ll}\text { - } & \text { Toxicity potential } \\
\text { - } & \text { Recyclability } \\
\text { - } & \text { Energy content }\end{array}$ & Provided \\
\hline Ljunberg [14] & $\begin{array}{ll}\text { - } & \text { Renewable } \\
\text { - } & \text { Recyclability } \\
\text { - } & \text { Durability }\end{array}$ & Not provided \\
\hline
\end{tabular}

\section{System of criteria for sustainable material choice}

Screening the literature sources shows that in quite a few studies several aspects for environmentally sound material choice are defined. Some of the authors have developed criteria for particular sectors (building sector $[7,8]$ ). Aspects from some research studies are presented in Table 1. The environmental aspects considered in these research studies are quite different and not easy to assess. From the studies presented in Table 1 only one presents quantifiable criteria [13]. Considering the environmental impacts of the PC desktop unit (see previous chapter), the aspects for environmentally-sound material choice are presented in Figure 1. 


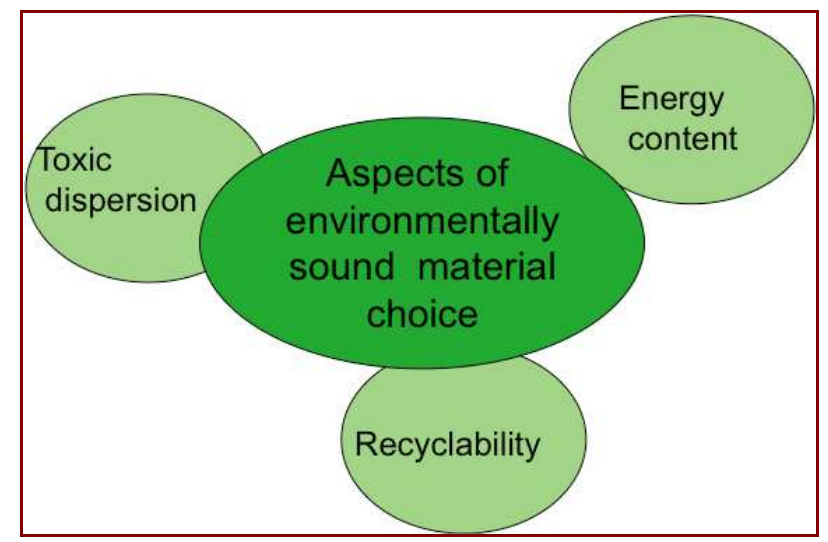

Fig.1. Aspects of environmentally-sound material choice

These criteria correspond very well with the work of Nissen [13], which can also be explained by the fact that the study was devoted to the environmental impact of electronic products. A closer look into these aspects - toxic dispersion, energy content and recyclability, and their inter-linkage is presented in the following chapters.

\section{Energy content}

Energy content of the raw material is expressed as MJ of the energy necessary to extract and produce one $\mathrm{kg}$ of the raw material, and this information can be easily found in literature. Obviously, the total energy content depends on the amount of the material required. Shaping and further processing of the material requires some energy as well, but it is usually less than initial production.

Energy content also depends on recyclability, e.g., usually the energy necessary for recycling of the materials is less than the energy used for primary production. Therefore, if the material is recycled, this lowers the total energy demand of the whole system. Figure 2 represents the energy content of some of the materials in a logarithmic scale. This scale is very convenient for splitting the range into five parts in order to characterize the energy content from low to very high.

\section{Recyclability}

Recyclability depends on various factors:

1. Inherent properties of the material;

2. Design of the final product $(\%$ of decrease of inherent recyclability) -the pure technical design also influences recyclability. For example, if the material is easy to separate during dismantling, or the exact opposite - it is very difficult to separate. Currently the sorting and recycling techniques are rapidly developing which make is possible to increase the percentage of recycled material [2];

3. End-of-life scenario (\% distribution of the whole product, e.g., the materials contained in the waste streams for recycling, incineration and landfills);

4. Amount of material.

To develop a set of criteria for inherent recyclability properties of the material, an analogous approach to the EU waste management hierarchy [15] can be used (see Figure 3). 


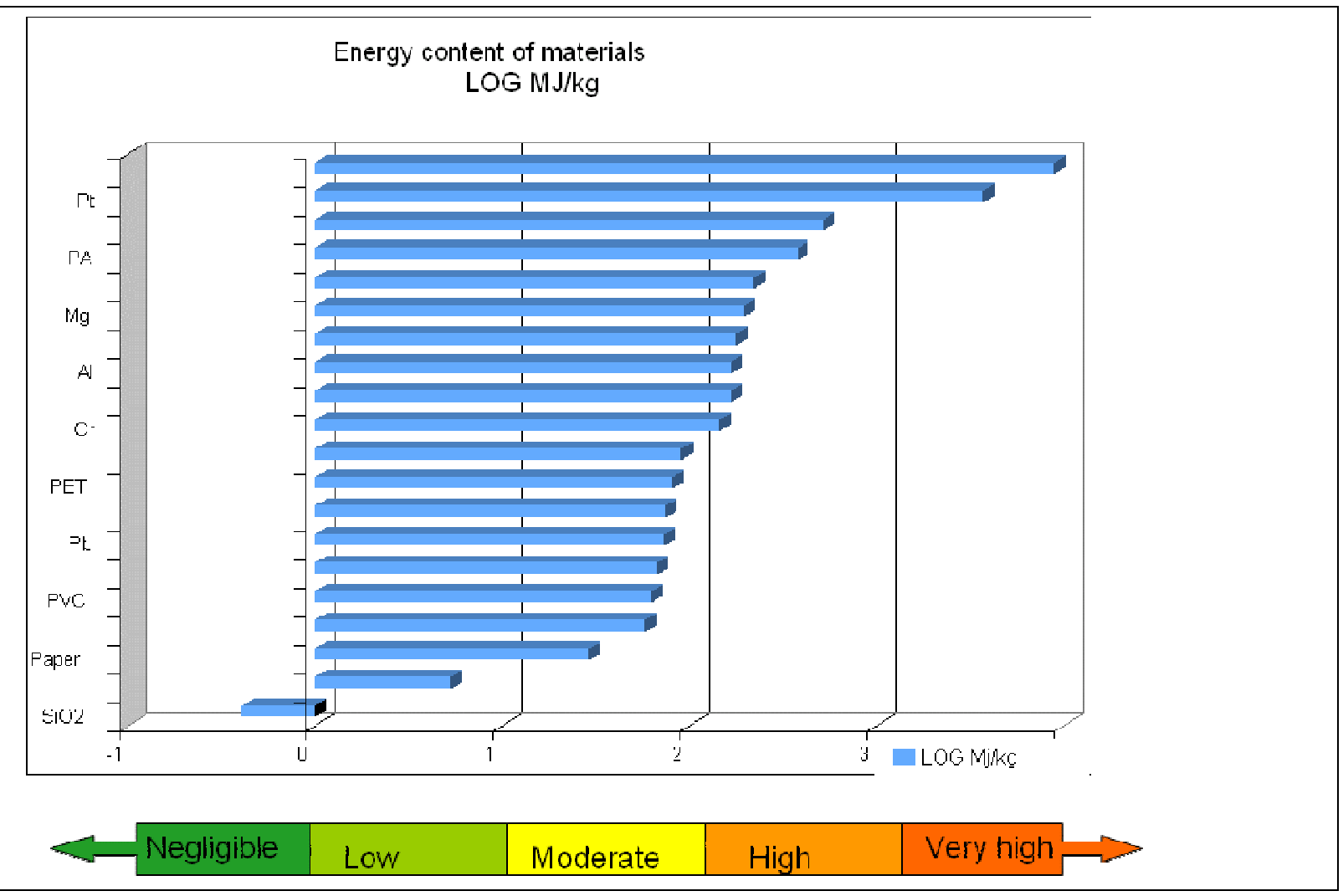

Fig.2. Energy content of some of the materials [data from 13]
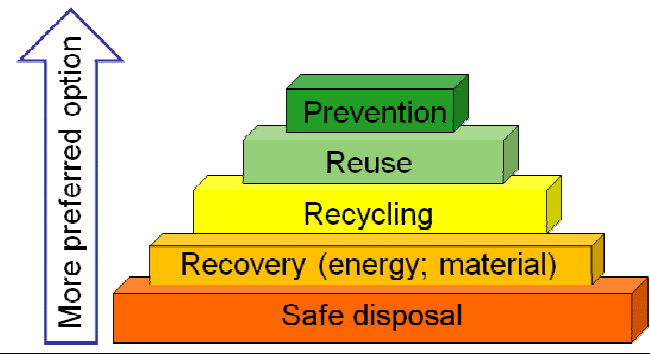

Fig.3. Waste hierarchy

Based on this analogy, the following scale can be proposed, see Table 2 .

Recyclability scale

Table 2.

\begin{tabular}{|c|c|}
\hline Value for non-recyclability & Description \\
\hline Negligible & Reuse of the product or a part of it \\
\hline Low & Recyclable, the same quality \\
\hline Moderate & Recyclable, but lower quality \\
\hline High & Energy recovery, inclusion in unrecyclable materials \\
\hline Very high & Disposal \\
\hline
\end{tabular}




\section{Toxic dispersion}

The toxicity of the materials depends on the content of toxic substances. Further on, the whole toxic impact depends on the inherent toxicity of the substances, as well as on the exposure patterns:

- the mobility of the substance and partitioning in the environment;

- the strength of binding to the product matrix (e.g. whether the chemical can be washed out from the surface);

- use of the product (how much and in which environmental medium the chemical is released, how much it is directly exposed to the person - user of the product);

- end-of-life scenario (also with regard to occupational health risks).
Various methods exist for the characterization of toxic materials, but each of them has some drawbacks. Unfortunately, the current LCA methodologies regarding the impact assessment of chemicals is insufficiently developed as only some of the endpoints for human toxicity are considered $[6,16]$ (see examples in Table 3). Therefore, in practical situations, the current LCA results regarding toxic chemicals are insufficient to avoid even known risks and thus the use of additional chemicals risk assessment tools is recommended.

Most often, the existing eco-design guidelines provide lists of undesired substances. Such lists are appreciated by designers but the weakness of such lists is a time delay (the time span between new findings on substance properties and their inclusion in the lists), and only the most commonly used substances and the most hazardous ones are considered during the elaboration of such lists

Aspects of material selection in the environmental product design $[6,16]$

Table 3.

\begin{tabular}{|c|c|c|}
\hline Method & Ecotoxicity & Human toxicity \\
\hline CML 2001 & $\begin{array}{cc}\text { - } & \text { Freshwater Aquatic toxicity } \\
\text { potential (FAETP) } \\
\text { - } \\
\text { Marine Aquatic toxicity } \\
\text { potential (MAETP) } \\
\text { - } \\
\text { Terrestrial toxicity potential } \\
\text { (MAETP) }\end{array}$ & - Human toxicity potential (HTP) \\
\hline $\begin{array}{c}\text { Ecoindiacator } \\
99\end{array}$ & - Ecosystem quality, Ecotoxicity & $\begin{array}{l}\text { - Human health, Carcinogenic effects } \\
\text { - Human health, Respiratory (inorganic) } \\
\text { - Human health, Respiratory (organic) }\end{array}$ \\
\hline $\begin{array}{l}\text { Impact } 2002+ \\
(\mathrm{v} 2.0)\end{array}$ & $\begin{array}{c}\text { - Aquatic ecotoxicity - Midpoint } \\
\text { - Terrestrial ecotoxicity - } \\
\text { Midpoint }\end{array}$ & $\begin{array}{l}\text { - } \quad \text { Carcinogens - Midpoint } \\
\text { - } \quad \text { Non-carcinogens - Midpoint } \\
\text { - } \quad \text { Respiratory effects - Midpoint }\end{array}$ \\
\hline
\end{tabular}

Other guidelines focus on the classification results of the substances according to the set of criteria in the Directive 67/548/EEC [17] (see overview in Table 4). All of these instruments are developed for different purposes - the Column model was developed for the evaluation of occupational risks, the TPI - for products, EHS - for choice of environmentally sound substances, the undesired substances in EU Eco-labelled products provide criteria for product development. Most of the tools in Table 4 provide ranking of the substances depending on properties, but eco-label criteria are exclusive: merely providing a list of the properties of substances, which may not be present in the product. Criteria for the most critical hazard endpoints are also different (see differences between the TPI and Column model), the EHS focuses on PBT-like substances (PBT: persistent, bio-accumulative, and toxic).

As mentioned above, the chemical impact - or so-called "toxic dispersion" - depends on the toxicity of the chemical (inherent properties) and its exposure patterns. Currently, only one tool - EHS - takes into account all of these factors, others only take into account the chemicals' inherent hazardous properties, and amount. 
Toxicity criteria in tools of chemical risk assessment based on chemicals' classification

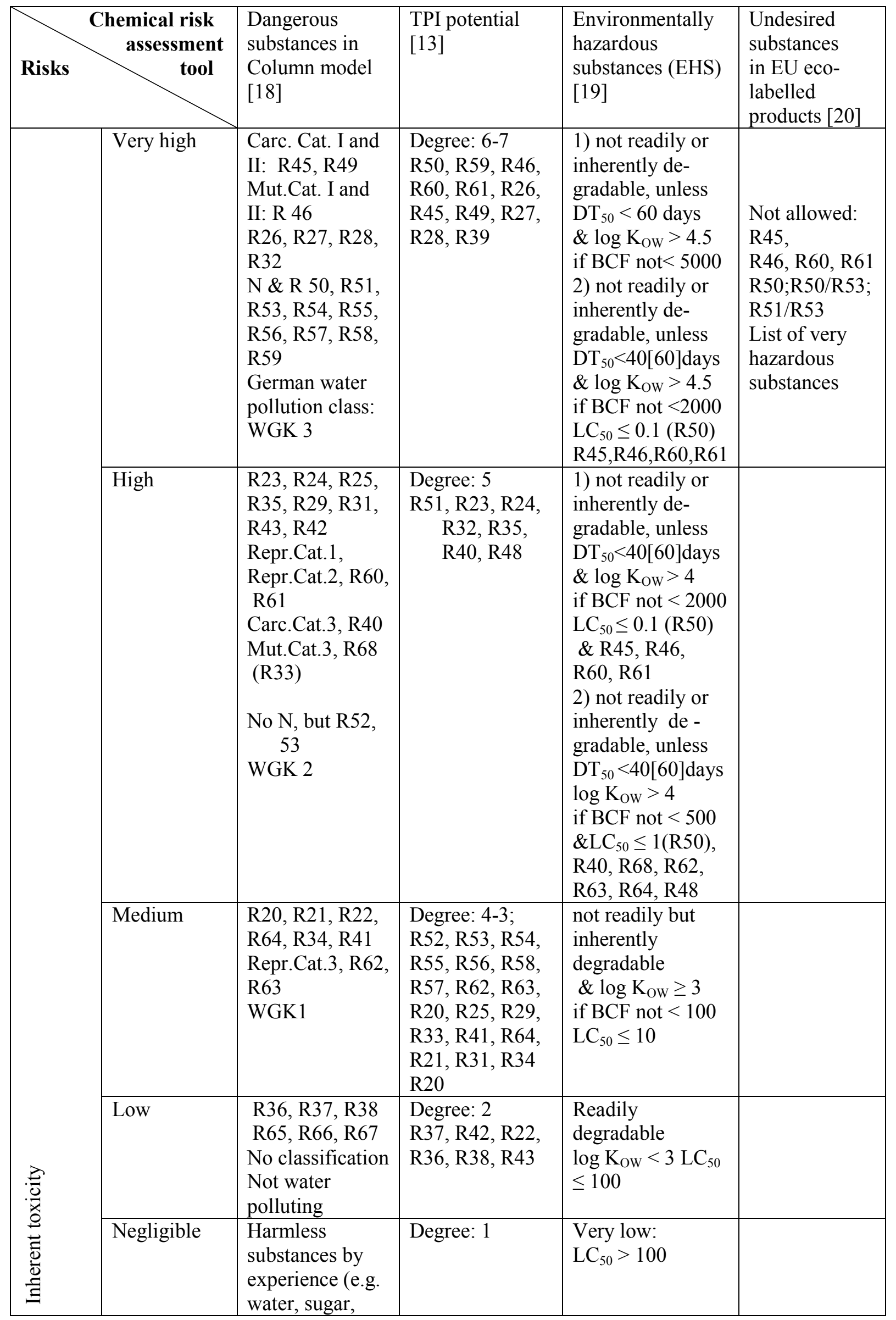




\begin{tabular}{|l|l|l|l|l|}
\hline \multicolumn{1}{|c|}{$\begin{array}{c}\text { Chemical risk } \\
\text { assessment } \\
\text { tool }\end{array}$} & $\begin{array}{l}\text { Dangerous } \\
\text { substances in } \\
\text { Column model } \\
{[18]}\end{array}$ & $\begin{array}{l}\text { TPI potential } \\
{[13]}\end{array}$ & $\begin{array}{l}\text { Environmentally } \\
\text { hazardous } \\
\text { substances (EHS) } \\
{[19]}\end{array}$ & $\begin{array}{l}\text { Undesired } \\
\text { substances } \\
\text { in EU eco- } \\
\text { labelled } \\
\text { products [20] }\end{array}$ \\
\hline & $\begin{array}{l}\text { paraffin and } \\
\text { similar) }\end{array}$ & Amount & $\begin{array}{l}\text { Amount, mobility, } \\
\text { binding to matrix, } \\
\text { use conditions, } \\
\text { indirect releases }\end{array}$ & $\begin{array}{l}\text { Amount (part } \\
\text { 25 g) }\end{array}$ \\
\hline Other aspects & No & & & \\
\hline
\end{tabular}

The next step of the work will be to develop a criteria system suited for product development, taking into account the most important endpoints and utilizing information on chemicals in the supply chain (e.g., classification and labelling). The criteria system will also take into consideration that the EU chemicals' classification- labelling system is currently undergoing changes due to the implementation of the GHS system [21].

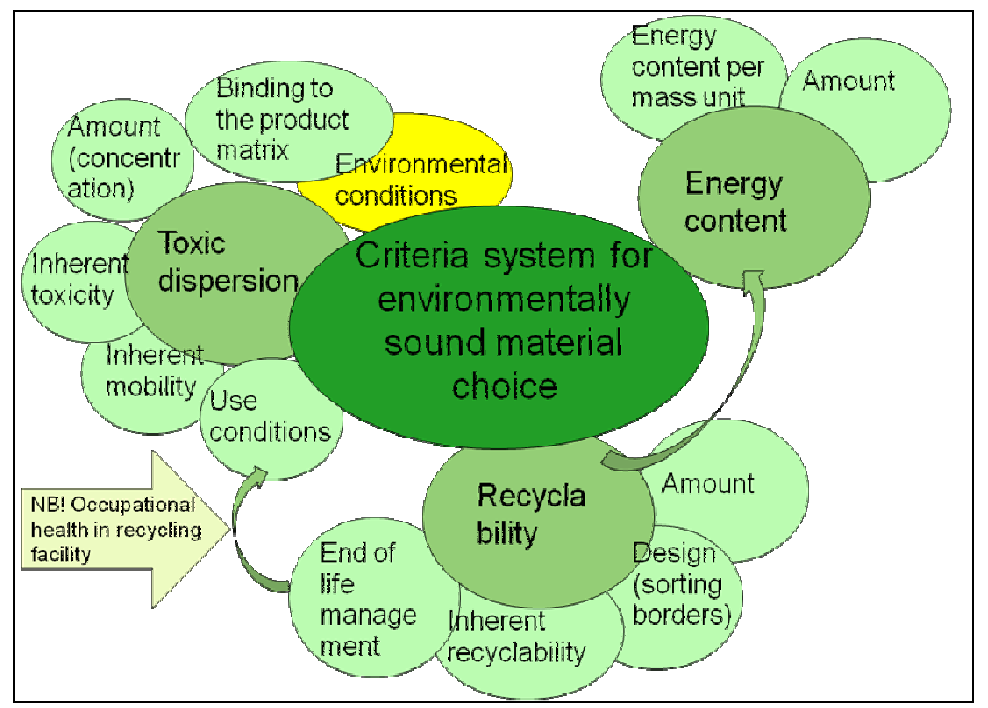

Fig.4. Set of criteria for environmentally-sound material choice

\section{Conclusion}

Based on these considerations, a set of criteria for the material choice can be developed (see Figure 4). This criteria system is based on three main criteria - toxicity, energy, and recyclability, which correspond to the main impact areas of material choice, as concluded from the published LCA studies $[3,4,5,6]$. These criteria are also linked to each other, e.g., with increasing recyclability one can decrease the energy content, as well as the toxic dispersion. The important innovation in this list of criteria would be that the product design - product structure - and use patterns (including end-of-life scenario) are linked to energy content, recyclability and toxicity.

The next step would be the development of quantifiable values for this criteria system (expressed in five units) and the design of a matrix with interrelations, in order to make it more applicable for the product design process as a screening tool that is more easily implemented than a complete LCA study. Additionally, such an approach in the evaluation of materials would promote the "cradle to cradle" philosophy.

\section{References}

1. Directive 2005/32/EC of 6 July 2005 establishing a framework for the setting of Eco-design requirements for energy-using products and amending Council Directive 92/42/EEC and Directives 96/57/EC and 2000/55/EC, amended by 2008/28/EC

2. Knight P, Jenkins J.O., Adopting and applying ecodesign techniques: a practitioners perspective Journal of Cleaner Production, Volume 17, Issue 5, March 2009, P. 549-558 
3. Choi, B.; Shin, H.; Lee, S.; Hur, T., Life cycle assessment of a personal computer and its effective recycling rate, International Journal of Life Cycle Assessment, Volume 11, Number 2 / March, 2006, P. $122-128$

4. LCA Study of the Product Group Personal Computers in the EU Ecolabel Scheme, March 1998. Atlantic Consulting and IPU, ec.europa.eu/environment/ecolabel/pdf/personal_co mputers/lcastudy_pc_1998.pdf [12.06.2009]

5. EC DG TREN (2005), Preparatory studies for Ecodesign Requirements of EuPs „LOT 3 - Personal Computers (desktops and laptops) and Computer Monitors. Final Report". Contract TREN/D1/402005/LOT3/S07.56313), Lot 3, Personal Computers (desktops and laptops) and Computer Monitors, Final Report (Task 1-8), IVF Industrial Research and Development Corporation, 2005

6. EPIC-ICT, Project no. 513673 (SSPI), Development of Environmental Performance Indicators for ICT Products on the example of Personal Computers, Deliverable 3: Short version, Data needs and data collection, Generic Modules, Environmental impacts, Impact assessment and weighting, Environmental interpretation and evaluation, May 2006, http://www.epic-ict.org/ [12.06.2009]

7. Abeysundara U.G.Y, Babel S., Piantanakulchai M., A matrix for selecting sustainable floor coverings for buildings in Sri Lanka, Journal of Cleaner Production, Volume 17, Issue 2, January 2009, P. 231-238

8. Castro-Lacouture D., Sefair J.A., Flórez L., Medaglia A.L., Optimization model for the selection of materials using a LEED-based green building rating system in Colombia, Building and Environment, Volume 44, Issue 6, June 2009, P. $1162-1170$

9. Materials and Design, by M. Ashby and K. Johnson. Published by Butterworth- Hinemann, U. K., 2003, pp. 1-277

10. Eco-design pilot, http://www.Eco-design.at/, [12.06.2009]

11. Luttropp C., Lagerstedt J., Eco-design and The Ten Golden Rules: generic advice for merging environmental aspects into product development, Journal of Cleaner Production, Volume 14, Issues 15-16, 2006, P. 1396-1408,

12. Inženiermateriālu īpašības un marḳēšana / J. Ozoliņš, Ė. Geriņš, G. Muižnieks - Rīga, 2008. - 60 lpp, Rīgas Tehniskā universitāte

13. Nissen, N.F., Entwicklung eines ökologischen Bewertungsmodells zur Beurteilung elektronischer Systeme, Doctoral Dissertation accepted by: Technical University of Berlin, Department of Electrical Engineering, 2001-02-15, 202 p.
14. Ljungberg L.Y., Materials selection and design for development of sustainable products

15. Materials \& Design, Volume 28, Issue 2, 2007, P. 466-47

16. Directive 2006/12/EC of the European Parliament and of the Council of 5 April 2006 on waste (Text with EEA relevance)

17. Hauschild M., Goedkoop M., Guinée J., Heijungs R., Handbook, Background Document: Analysis of existing Environmental Impact Assessment methodologies for use in LCA, International Reference Life Cycle Data System (ILCD), DRAFT GUIDANCE DOCUMENT FOR PUBLIC CONSULTATION, commissioned by EC Joint Research Centre contract no.383163 F1SC concerning "Definition of recommended Life Cycle Impact Assessment (LCIA) framework, methods and factors", June 2009, P.122

18. DIRECTIVE 67/548/EEC of 27 June 1967 on the approximation of laws, regulations and administrative provisions relating to the classification, packaging and labelling of dangerous substances

19. Smola T., The Column Model, An aid to substitute assessment, Berufsgenossenschaftliches Institut für Arbeitsschutz - BGIA, December 2006, www.hvbg.de/bgia, [12.06.2009]

20. Ahrens A., Böhm E., Heitmann K., Hillenbrand T. Guidance for the use of environmentally sound substances, Part I and II, Berlin 2003, P. 66

21. COMMISSION DECISION (11.04.2005) establishing ecological criteria and the related assessment and verification requirements for the award of the Community eco-label to personal computers (notified under document C(2005) 1024) (2005/341/EC)

22. Globally Harmonized System of classification and labelling of chemicals, United Nations, New York and Geneva, 2000, P431 
Jana Simanovska, Kārlis Valters, Gatis Bažbauers, Kritēriju kopas kā ekodizaina instrumenta izstrāde izvēlēto materiālu ietekmes uz vidi novērtēšanai

Ekodizains ir daļa no produkta izstrādes procesa. Tā mērksis ir samazināt produkta ietekmi uz vidi visā tā dzīves ciklāa. Mūsdienās ekodizaina nozīme aizvien pieaug, un likumdevēji šo pieeju to iestrādā arī jaunākajos likumdošanas aktos. Tai pašā laikā ekodizaina ieviešana rūpniecībā kavējas, jo vairums izstrādāto ekodizaina instrumentu un vadlīniju orientējas uz stratēgisko līmeni, bet trūkst praktisku ieviešanas instrumentu. Lai veicinātu ekodizaina ieviešanu rūpniecībāa, nepieciešams izstrādāt vienkāršus instrumentus, kas vadās no jaunākajiem zinātniskajiem atklājumiem un padara tos ieviešamus ražošanā produkta izstrādes procesā. Š̀ raksta mērkis ir iepazīstināt ar apsvērumiem kritēriju kopas izstrādei materiālu izvēlei, n̦emot vērā publicēto dzīves ciklu analī̌̌u rezultātus un datus par materiālu ietekmi uz vidi. Piedāvātā kritēriju kopa balstās uz trim galvenajiem kritērijiem - toksiskumu, reciklējamību (atkārtotas izmantošanas spēju), energíjas patēriņu, kas atbilst citu zinātnieku publicēto dzīves cikla anaļı̌žu pētījumu rezultātiem. Šie kritēriji ir saistīti viens ar otru - palielinot reciklējamību, var samazināt energijas patērinuu un toksisku vielu izkliedi. Inovatīva pieeja šajā kritēriju kopā saistās ar to, ka produkta dizains - produkta struktūra un izmantošanas veids ir saistītts ar reciklējamību, toksiskumu un energijas patēriņu. Nākošais solis kritēriju sistēmas pilnveidošānāir kvantificējamu vērtību izstrāde (5 vien̄̄bas), lai piemērotu šo kritēriju izmantošanu produkta izstrādes procesā, tas ir, radītu instrumentu ātra, lai gan virspusēja, pārskata iegūšanai.

Jana Simanovska, Kārlis Valters, Gatis Bažbauers, Development set of criteria as an eco-design tool for the evaluation of environmental impact of material choice

Eco-design is part of the product design process aimed at reducing the environmental impacts of products during their entire lifecycle. Nowadays, the eco-design concept becomes more and more important, and it is also incorporated in the latest developments in legislation. However, with regard to the implementation of eco-design, many guidelines and tools still focus on the strategic level, but the practical tools are underdeveloped. In order to promote eco-design in the industry, there is a need for the further development of more practical tools, taking into account the scientific findings, but also making them applicable into a product design process. The intention of this paper is to present major considerations in order to develop a set of criteria for the material choice taking into account LCA studies and available data regarding environmental performance of materials. The proposed criteria system is based on three main criteria toxicity, energy, recyclability, which corresponds to the main impact areas of material choice according to findings from the published LCA studies. These criteria are also linked to each other - e.g. with increasing recyclability one can decrease the energy content, as well as the toxic dispersion. The important innovation in this list of criteria would be that the product design - product structure -and use patterns (incl. end of life scenario) is linked to energy content, recyclability and toxicity. The next step would be development of the quantifiable values of this criteria system (expressed in 5 units), in order to make it more applicability of a quick screening tool in the product design process.

Яна Симановска, Карлис Валтерс, Гатис Бажбауерс, Набор критериев как разработка инструментов экодизайна для оценки влияния на среду выбранных материалов

Экодизайн является частью проиесса разработки продукта. Его иель - уменьшить влияние всего жизненного иикла продукта на среду. В наши дни значение экодизайна постоянно растёт, и законодатели включают его и в новые законодельныи актыл. В то же время, внедрение экодизайна в промышленность задерживается, так как большинство разработанных инструментов и руководств экодизайна ориентируется на стратегический уровень, а практических инструментов внедрения не хватает. Чтобы способствовать внедрению экодизайна в промышленность, нужсно разработать простые инструменты, которые будут руководствоваться новыми научными открытиями и делать возможным их использование в процессе разработки продуктов.

Цель этой статьи познакомить с соображениями о разработке набора критериев для выбора материалов, принимая во внимание результать анализов опубликованных жизненных ичиклов и данные о влиянии материалов на среду. Предложенный набор критериев базируется на трёх основных критериях - токсичность, рециклизация (возможность вторичного использования), затрата энергии, которые соответствуют результатам опубликованных другими учёными исследовательских анализов жизненных ииклов. Эти критерии связаны между собой - повышая возможность рециклизации, можно уменьшить затрать энергии $и$ рассеивание токсических веществ. Иновативный подход в наборе критериев связан с тем, что дизайн продукта структура продукта и способ его использования связан с рециклизацией, токсичностью и расходом энергии. Следуюшим шагом совершенствования системь критериев является разработка количественных величин (5 единии) для применения этих критериев в процессе разработки продукта, то есть создание быстрого, хоть и поверхностного, обзора инструментов. 